\title{
STIM1 wt Allele
}

National Cancer Institute

\section{Source}

National Cancer Institute. STIM1 wt Allele. NCI Thesaurus. Code C52380.

Human STIM1 wild-type allele is located in the vicinity of 11 p15.5 and is approximately $238 \mathrm{~kb}$ in length. This allele, which encodes stromal interaction molecule 1 protein, is involved in hematopoietic activities and stromal cell adherence.Defects in the gene may cause rhabdomyosarcoma and rhabdoid tumors. 